\title{
Glutamatergic Transmission Aberration: A Major Cause of Behavioral Deficits in a Murine Model of Down's Syndrome
}

\author{
Gurjinder Kaur, ${ }^{1}$ Ajay Sharma, ${ }^{1}$ Wenjin Xu, ${ }^{1,2}$ Scott Gerum, ${ }^{1}$ Melissa J. Alldred, ${ }^{1,3}$ Shivakumar Subbanna, ${ }^{1}$ \\ Balapal S. Basavarajappa, ${ }^{1,6}$ Monika Pawlik, ${ }^{1}$ Masuo Ohno, ${ }^{1,3}$ Stephen D. Ginsberg, ${ }^{1,3,5}$ Donald A. Wilson, ${ }^{1,2}$ \\ David N. Guilfoyle, ${ }^{1}$ and Efrat Levy ${ }^{1,3,4}$ \\ ${ }^{1}$ Nathan S. Kline Institute, Orangeburg, New York, 10962, ${ }^{2}$ Department of Child and Adolescent Psychiatry, ${ }^{3}$ Department of Psychiatry, ${ }^{4}$ Department of \\ Biochemistry and Molecular Pharmacology, and ${ }^{5}$ Department of Physiology and Neuroscience, NYU Langone School of Medicine, New York, New York, \\ 10016, and ${ }^{6}$ Department of Psychiatry, College of Physicians and Surgeons, Columbia University, New York, New York 10032
}

Trisomy 21, or Down's syndrome (DS), is the most common genetic cause of intellectual disability. Altered neurotransmission in the brains of DS patients leads to hippocampus-dependent learning and memory deficiency. Although genetic mouse models have provided important insights into the genes and mechanisms responsible for DS-specific changes, the molecular mechanisms leading to memory deficits are not clear. We investigated whether the segmental trisomy model of $\mathrm{DS}, \mathrm{Ts}[\mathrm{Rb}(12.1716)] 2 \mathrm{Cje}$ (Ts2), exhibits hippocampal glutamatergic transmission abnormalities and whether these alterations cause behavioral deficits. Behavioral assays demonstrated that Ts2 mice display a deficit in nest building behavior, a measure of hippocampus-dependent nonlearned behavior, as well as dysfunctional hippocampus-dependent spatial memory tested in the object-placement and the Y-maze spontaneous alternation tasks. Magnetic resonance spectra measured in the hippocampi revealed a significantly lower glutamate concentration in Ts2 as compared with normal disomic (2N) littermates. The glutamate deficit accompanied hippocampal NMDA receptorl (NMDA-R1) mRNA and protein expression level downregulation in Ts2 compared with $2 \mathrm{~N}$ mice. In concert with these alterations, paired-pulse analyses suggested enhanced synaptic inhibition and/or lack of facilitation in the dentate gyrus of Ts2 compared with $2 \mathrm{~N}$ mice. Ts2 mice also exhibited disrupted synaptic plasticity in slice recordings of the hippocampal CA1 region. Collectively, these findings imply that deficits in glutamate and NMDA-R1 may be responsible for impairments in synaptic plasticity in the hippocampus associated with behavioral dysfunctions in Ts 2 mice. Thus, these findings suggest that glutamatergic deficits have a significant role in causing intellectual disabilities in DS.

Key words: Down's syndrome; glutamate; LTP; NMDA receptors; spatial memory

\section{Introduction}

Down's syndrome (DS) is a genetic disease caused by trisomy of human chromosome 21 (HSA21), associated with developmental brain abnormalities (Wisniewski et al., 1984; Lott, 2012) and early intellectual disabilities (Lott and Dierssen, 2010). After the third decade of life, DS is associated with Alzheimer-type neuropathology and dementia (Wisniewski et al., 1985; Leverenz and Raskind, 1998; Sheehan et al., 2014). Alzheimer's disease (AD) pathology is associated with triplication of the amyloid- $\beta$ precursor protein (APP) gene located on HSA21 (Kang et al., 1987). To date, the mechanism(s) underlying these intellectual disabilities and age-related cognitive decline in DS is unclear, although data suggest that a wide array of neurochemical changes may compro-

Received Dec. 19, 2013; revised Feb. 14, 2014; accepted Feb. 15, 2014.

Author contributions: G.K. and E.L. designed research;G.K., A.S., W.X., S.G., M.J.A., S.S., B.S.B., M.P., M.O., S.D.G., D.A.W., and D.N.G. performed research;G.K., W.X., M.J.A., B.S.B., S.D.G., D.A.W., D.N.G., and E.L. analyzed data;G.K., S.D.G., and E.L. wrote the paper.

This work is supported by the National Institutes of Health (AG017617 to E.L. and S.D.G., AG037693 to D.A.W. and E.L., and AA019443 to B.S.B.).

The authors declare no competing financial interest.

Correspondence should be addressed to Gurjinder Kaur, Nathan S. Kline Institute, 140 Old Orangeburg Road, Orangeburg, NY 10962. E-mail: gkaur@nki.rfmh.org.

DOI:10.1523/JNEUROSCI.5338-13.2014

Copyright $\odot 2014$ the authors $\quad 0270-6474 / 14 / 345099-08 \$ 15.00 / 0$ mise cognitive performance in DS (Cataldo et al., 2000; Lott, 2012). Changes in several neurotransmitters and their cognate receptors have been demonstrated in DS individuals (Yates et al., 1986; Reynolds and Warner, 1988; Bar-Peled et al., 1991; Risser et al., 1997; Oka and Takashima, 1999; Whittle et al., 2007; Bhattacharyya et al., 2009). Specifically, decreased concentrations of glutamate, aspartate, GABA, serotonin, norepinephrine, and dopamine had been found in postmortem tissue samples from several brain regions of adult DS patients (Godridge et al., 1987; Reynolds and Warner, 1988; Risser et al., 1997; Rueda et al., 2012).

Trisomic mouse models of DS have provided important insights into the genes and mechanisms responsible for DS-specific changes (Das and Reeves, 2011). A mouse model of DS that has been extensively studied is the segmental trisomy model Ts65Dn (Davisson et al., 1990; Holtzman et al., 1996; Granholm et al., 2000). Abnormal hippocampal synaptic plasticity and behavioral deficits in Ts65Dn mice have been attributed to changes in glutamatergic and GABAergic neurotransmitter dysfunctions (Siarey et al., 2006; Best et al., 2012; Cramer and Galdzicki, 2012; Colas et al., 2013). Studies of the Ts65Dn mouse have unveiled learning and memory deficits putatively dependent on the excessive signaling via NMDA receptors (Costa et al., 2008; Boada et al., 2012; Cramer and Galdzicki, 2012). The NMDA antagonist 
memantine has shown behavioral and physiological efficacy in Ts65Dn mice (Lockrow et al., 2011; Scott-McKean and Costa, 2011), which have yet to be translated fully into human DS (Boada et al., 2012; Hanney et al., 2012).

The present investigation employs a trisomic mouse model of DS, the Ts2 mouse, which bears a partial trisomic chromosomal rearrangement translocated to mouse chromosome 12 (MMU12), containing approximately half of the genes of mouse chromosome 16 (MMU16), which are orthologous to HSA21 (Villar et al., 2005). This genetic configuration enables fertility in males and transmits the DS segmental trisomy through the female germline, granting the Ts2 mouse model an advantage over the Ts65Dn model (Villar et al., 2005; Levine et al., 2009).

We hypothesize that the hippocampus-dependent behavioral deficits in DS are in part the result of a dysfunctional glutamatergic system. To address this, we investigated whether the Ts 2 mice exhibit hippocampal glutamatergic transmission and NMDA receptor alterations and whether these may contribute to anomalous synaptic plasticity in the hippocampus and further behavioral deficits.

\section{Materials and Methods}

Animals. A breeding colony of $\mathrm{Ts}[\mathrm{Rb}(12.1716)] 2 \mathrm{Cje}$ (Ts2) mice was maintained on $\mathrm{B} 6 \mathrm{EiC} 3 \mathrm{SnF} 1 / \mathrm{J}$ background. Trisomic mice and disomic controls were studied at 8 months of age. Both females and males were used for all analyses. All animal procedures were performed following the National Institutes of Health guidelines with approval from the Institutional Animal Care and Use Committee at the Nathan S. Kline Institute for Psychiatric Research.

Nesting behavior. Mice were individually housed for at least $24 \mathrm{~h}$ in clean plastic cages with $\sim 1 \mathrm{~cm}$ of corn cob bedding lining the floor and identification cards coded to render the experimenter blind to the sex and genotype of each subject. Two hours before the onset of the dark phase of the lighting cycle, each cage was supplied a commercially available nestlet of pressed cotton square (Ancare; Lillico). The next morning $(\sim 16 \mathrm{~h}$ later $)$ cages were inspected for nest building. Pictures were taken before evaluation for documentation. Nest construction was scored using the established system of Deacon (Deacon, 2006) with a 5 point system: 1 , nestlet not noticeably touched; 2 , nestlet partially torn up (50-90\% remaining intact); 3, mostly shredded nestlet but often no identifiable nest site; 4 , an identifiable, but flat nest; 5 , a (near) perfect nest with clear nest crater.

Object placement behavior. A hippocampal-dependent object-placement task was adapted for mice from previously described procedures (Luine et al., 2003; Macbeth et al., 2008). Mice were acclimated to an open Plexiglas arena $(20 \mathrm{~cm} \times 40 \mathrm{~cm} \times 20 \mathrm{~cm})$ lined with fresh corn cob bedding twice a day for 5 min each with intertrial intervals of 5 min on day 1 , and $4 \mathrm{~h}$ on day 2 . On the third day mice were placed in the same arena with two identical objects (A and B; amber glass vials, $2 \mathrm{~cm}$ diameter, $5 \mathrm{~cm}$ tall) placed equidistant to adjacent corners of the arena. Investigation duration was quantified over a 5 min time period (trial 1) then mice were returned to their litter cage. Investigation was scored as time of nose pointing toward the objects within $2 \mathrm{~cm}$. Objects and arena were wiped with $70 \%$ ethanol between each session. The alcohol odor was evaporated before each trial. Four hours after training, one object (B) was moved longitudinally to a position diagonal from the object retaining its original position. The side of the chamber with the displaced object (B) was alternated between animals to avoid any possibility of side preference, which may influence the results. Investigation time for each object was quantified as a percentage of total investigation time. Mice that did not investigate both objects within the training or test durations were removed from analysis, and the number of animals excluded did not vary between groups. Behavior on the training and testing days was videotaped for off-line analyses. An increased percentage of time spent exploring the displaced object (B) compared with the total time spent exploring both objects during testing was considered an index of enhanced performance in this task. Investigation times were compared within each condition between training and test trials using a Student's $t$ test to confirm the behavioral task effectiveness in controls. One-way ANOVA comparison of moved object investigation times during the test trial (trial 2) were made between Ts 2 and $2 \mathrm{~N}$ mice to determine statistical significance of variance.

$Y$-maze spontaneous alternation test. Spontaneous alternation in rats and mice refers to the natural tendency of rodents spontaneously to choose alternate arms in a Y-or T-maze. The Y-maze test is considered to be a test of hippocampal-based spatial working memory, devoid of fear, reward, or reinforcers (Hughes, 2004). The Y-maze equipment consists of a maze with its floors and walls constructed from dark opaque polyvinyl plastic. It has three equidistant arms (named A-C) with equal angles between all arms. Animals were initially placed within one arm, and the sequence and number of arm entries were recorded manually for each animal over an $8 \mathrm{~min}$ period. The percentage of entries in which all three arms was represented, e.g., $\mathrm{ABC}, \mathrm{CAB}$, or $\mathrm{BCA}$ but not $\mathrm{BAB}$, was recorded as an alternation to estimate spatial working memory. Arms were cleaned between the tests to remove odors and residues. The alternation score (\%) for each animal was defined as the ratio of the actual number of alternation to the possible number (defined as the total number of arm entries minus two) multiplied by 100 . The number of arm entries was used as an indicator for the exploratory activity.

Magnetic resonance. Male and female (25-35 g) Ts2 and disomic control mice were anesthetized using an isoflurane vaporizer set at the following: $3-4 \%$ for induction, $2 \%$ during piloting, and $1.5 \%$ during acquisition of spectra. After induction, mice were placed on the radiofrequency coil tray and restrained by the head using a bite bar and ear bars placed half way into the aural canal. Oxygen was used as the carrier gas and delivered at low flow rate $(\leq 0.5 \mathrm{~L} / \mathrm{min})$ to a cone positioned before the bite bar where gases were mixed with air and passed over the mouse nose. A small animal instruments monitoring unit (model 1025) was used for observing respiration, heart rate, and rectal temperature. Respiration was measured with a pressure transducer placed under the abdomen just below the ribcage. An infrared pulse oximeter sensor, placed on the tail, or hind foot, enabled heart rate monitoring. Body temperature was maintained using forced warm air, controlled by a feedback circuit between the heater and thermistor. All animals where maintained at $37 \pm$ $0.2^{\circ} \mathrm{C}$ verified by a thermosensor and respiration ranged between 50 and 70 breaths per minute with a median heart rate of 500 beats during scanning. The duration of a study for a single mouse did not exceed $2 \mathrm{~h}$. In vivo ${ }^{1} \mathrm{H}$ magnetic resonance spectroscopy (MRS) from the hippocampus was measured in these mice to investigate the metabolite concentrations in this specific brain region.

${ }^{1} H$ MRS. All data were obtained on a 7.0 tesla Agilent $40 \mathrm{~cm}$ bore system. The gradient coil insert had an internal diameter of $12 \mathrm{~cm}$ with a maximum gradient strength of $600 \mathrm{mT} / \mathrm{m}$ and minimum rise time of 200 $\mu$ s with customized second- and third-order shim coils. A Rapid volume transmit coil (72 mm ID) and a two-channel receive-only surface coil was used for radiofrequency (RF) transmission and reception. The shim settings for the selected voxel of interest were automatically adjusted using Fast, Automatic Shimming Technique by Mapping Along Projections (FASTMAP; Gruetter, 1993), a high-order shim method, which samples the magnetic field along a group of radial columns that focus on the center of a localized voxel. It is a method for optimizing the field homogeneity in a cubical local region.

The normal water signal used in MRS is 10,000 times stronger than the metabolite signals measured. To provide sufficient dynamic range to measure the metabolites of interest, the water signal must be first suppressed. This was achieved by using Variable Power RF pulses with optimized relaxation delays (VAPOR; Tkác et al., 1999). The spectral acquisition consisted of a short echo time Point Resolved Spectroscopy (PRESS) (Bottomley, 1987) sequence with the following parameters: repetition time $=4 \mathrm{~s}$, echo time $=7.5 \mathrm{~ms}$, number of averages $=512$, number of points $=2048$, and bandwidth of acquisition $=5 \mathrm{kHz}$, total acquisition time $=34 \mathrm{~min}$. Outer volume suppression was also used to minimize signal contamination by extracranial muscle and lipids. The voxel of interest size was $5 \mu \mathrm{l}\left(1 \times 2 \times 2.5 \mathrm{~mm}^{3}\right)$ placed in the hippocampus. An anatomical $\mathrm{T}_{2}$-weighted pilot scan was used to position the voxel of interest (coronal). These scans were acquired with a fast spin echo sequence with the following parameters: field of view $=20 \mathrm{~mm}$ with 
$256 \times 256$ matrix size, slice thickness $=0.5 \mathrm{~mm}$, number of slices $=8$, repetition time $=4 \mathrm{~s}$, echo train length $=8$, echo spacing $=15 \mathrm{~ms}$, effective echo time $=60 \mathrm{~ms}$, total acquisition time $=272 \mathrm{~s}$.

All data were processed using the LCModel software (Provencher, 1993). This software calculates the best fit to the acquired data of linear combination of model spectra acquired from in vitro solutions. The model spectra consist of all the metabolites of interests. The basis set used for the fitting was provided by S.W. Provencher for the field strength, sequences, and echo time used. An unsuppressed water signal was used for absolute concentration calculation. This has several advantages in that it is straightforward to implement, the water suppression option is simply turned off, and it also eliminates several sources of error such as voxel size and relaxation effects. The method assumes water concentrations for gray and white matter. The unsuppressed water signal was also used for eddy current compensation.

Western blot analysis. Mice were killed, brains were dissected, and the cortices and hippocampi were flash frozen on dry ice. Tissues were homogenized in lysis buffer: $20 \mathrm{~mm}$ Tris- $\mathrm{HCl}$, pH 7.4, $250 \mathrm{~mm}$ sucrose, $1 \mathrm{~mm}$ EDTA, and $1 \mathrm{~mm}$ EGTA with protease inhibitors $(5 \mu \mathrm{g} / \mathrm{ml}$ leupeptinantipain-pepstatin A mix and $1 \mathrm{~mm}$ PMSF). Protein concentration was determined by the BCA Protein Assay Kit (Pierce). Equal amounts (20 $\mu \mathrm{g}$ ) of total proteins were boiled in sample buffer (1\% SDS, $3 \%$ glycerol, $1.5 \% \beta$-mercaptoethanol, and $20 \mathrm{~mm}$ Tris- $\mathrm{HCl}, \mathrm{pH} 6.8)$ and separated by $15 \%$ Tris-glycine gel electrophoresis. The proteins were electrophoretically transferred onto a $0.2 \mu \mathrm{m}$ polyvinylidene fluoride membrane (Bio$\mathrm{Rad}$ ) in $2.5 \mathrm{~mm}$ Tris/19.2 mm glycine/20\% methanol transfer buffer. The membrane was blocked in 5\% milk (Bio-Rad) or 5\% bovine serum albumin in $10 \mathrm{~mm}$ Tris, $150 \mathrm{~mm}$ sodium chloride, $\mathrm{pH} 7.5$, and $0.1 \%$ Tween 20 , incubated with primary antibody overnight at $4^{\circ} \mathrm{C}$, and with secondary antibody for $1-2 \mathrm{~h}$ at room temperature. The membranes were incubated in chemiluminescent fluid (Pierce) for $5 \mathrm{~min}$, and chemiluminescence was visualized on Reflection Autoradiography film. $\beta$-Tubulin was blotted on the same, stripped membrane as an internal control for loading. The protein bands were scanned, optical density was calculated using the ImageJ software, and the ratio of protein intensity to $\beta$-tubulin in the same lane was calculated.

Antibodies used for Western blot analysis. The primary antibodies used were goat anti-NMDA-R1 polyclonal antibody (specific for GRIN2A subunit of NMDA receptor; 1:1000; Millipore) and mouse anti- $\beta$-tubulin monoclonal antibody (1:10,000; Sigma). The secondary antibodies used were horseradish peroxidase-conjugated anti-goat and anti-mouse antibodies (GE Healthcare).

Real-time qPCR. qPCR was performed in triplicate on RNA purified from CA1 or dentate gyrus (DG) microdissected samples from hippocampi of Ts 2 or $2 \mathrm{~N}$ hemibrains ( $n=7$ per genotype; Alldred et al., 2008; Ginsberg, 2008; Devi et al., 2010). TaqMan qPCR primers were used for mouse NMDA-R1 subunit (GRIN1; Mm00433800_m1; Life Technologies), $\alpha$-amino-3-hydroxy-5-methyl-4-isoxazole propionate glutamate receptor 1 subunit (GRIA1; Mm01342712_m1), $\alpha$-amino-3hydroxy-5-methyl-4-isoxazole propionate glutamate receptor 2 subunit (GRIA2; Mm01220174_m1), discs large homolog 4 (DLG4, formerly PSD-95; Mm00492207_m1), and the housekeeping genes glyceraldehyde3-phosphate dehydrogenase (GAPDH; Mm99999915_g1), succinate dehydrogenase complex, subunit A (SDHA; Mm01352360_m1), and hypoxanthine phosphoribosyltransferase 1 (Hprt1; Mm01318747_g1). Samples were assayed on a real-time qPCR cycler (7900HT; Applied Biosystems) in 96-well optical plates covered with optical adhesive film. Standard curves and cycle threshold were generated using standards obtained from total mouse brain RNA. The delta delta cycle threshold (ddCT) method was used to determine relative gene level differences between Ts 2 and $2 \mathrm{~N}$ mice with housekeeping gene qPCR products used as a control, and expression levels were presented as the percentage of vehicle controls (Alldred et al., 2012). Negative controls consisted of the reaction mixture without input RNA.

In vivo hippocampal physiology. Mice were anesthetized with urethane $(1.25 \mathrm{~g} / \mathrm{kg})$ and head fixed to a stereotaxic apparatus for in vivo pairedpulse recording. The skin was removed to expose the skull and holes were drilled over the DG and perforant path using stereotaxic coordinates described previously (Paxinos and Franklin, 2000). For the paired-pulse protocol, a stimulating electrode was lowered into the perforant path and a tungsten microelectrode $(1-5 \mathrm{M} \Omega)$ was used to record in the DG. Signals were acquired and analyzed with Spike2 (CED). Briefly, the current used for paired-pulse stimulation for each mouse was obtained by taking half of the current that provided the maximal evoked response in the DG for that animal. Then, five pairs of consecutive electrical pulses at each of four time intervals $(20,50,100$, and $300 \mathrm{~ms})$ were given and the responses recorded (interpair interval was $10 \mathrm{~s}$ ). The paired-pulse ratio was obtained by calculating the ratio of the average slope of the second (test) evoked response divided by the average slope of the first (conditioning) evoked response at each time interval.

Long-term potentiation. Mice were killed by cervical dislocation followed by decapitation. Hippocampi were quickly removed. Transverse hippocampal slices $(400 \mu \mathrm{m})$ were cut and recorded according to standard procedures (Basavarajappa and Subbanna, 2014). Following cutting, hippocampal slices were transferred to a recording chamber where they were maintained at $29^{\circ} \mathrm{C}$ and perfused with artificial CSF (ACSF) continuously bubbled with $95 \% \mathrm{O}_{2}$ and $5 \% \mathrm{CO}_{2}$. The ACSF composition was as follows (in mM): $124.0 \mathrm{NaCl}, 4.4 \mathrm{KCl}, 1.0 \mathrm{Na}_{2} \mathrm{HPO}_{4}, 25.0$ $\mathrm{NaHCO}_{3}, 2.0 \mathrm{CaCl}_{2}, 2.0 \mathrm{MgSO}_{4}$, and 10.0 glucose, osmolarity 290-300. CA1 field EPSPs (fEPSPs) were recorded by placing both the stimulating and the recording electrodes in CA1 stratum radiatum. Basal synaptic transmission (BST) was determined by plotting the stimulus voltages against slopes of fEPSPs. For long-term potentiation (LTP) experiments, a 10 min baseline was recorded every minute at an intensity that evokes a response $\sim 35 \%$ of the maximum evoked response. LTP was induced using theta-burst stimulation (4 pulses at $100 \mathrm{~Hz}$, with the bursts repeated at $5 \mathrm{~Hz}$, and each tetani including $3 \times 10$ burst trains separated by $15 \mathrm{~s}$ ). Responses were recorded for $2 \mathrm{~h}$ and measured as fEPSP slope expressed as percentage of baseline.

Statistical analyses. Data are presented as mean \pm SEM. One-way ANOVA followed by post hoc multiple-comparison Bonferroni's tests was used to evaluate the differences between genotypes. qPCR results were analyzed using one-way ANOVA and post hoc analysis (NeumannKeuls test; level of statistical significance was set at $p<0.05$ ).

\section{Results}

\section{Nesting dysfunction in the Ts2 mouse model}

To test nest building, which is a measure of hippocampusdependent nonlearned innate behavior, the method of Deacon (Deacon, 2006) was followed (see Materials and Methods). Ts2 mice scaled poorly in nest formation as compared with their $2 \mathrm{~N}$ disomic littermates (Fig. 1A). We did not find gender differences between both genotypes (Fig. $1 B$ ). To assess the existence of this behavior further, we extended the housing with nestlet material so that in the due course it might induce nest construction. Noticeably, nestlet material remained as untouched or poorly built as a nest for up to $3 \mathrm{~d}$ by the Ts 2 mice (data not shown).

\section{Spatial memory dysfunctions in the Ts 2 mouse model}

To investigate whether the trisomic mice have dysfunction in hippocampus-dependent spatial memory performance, mice were tested in the object-placement spatial memory task. All the mice tested for this task explored both objects during the training and testing. Figure $2 A$ shows data from the training trial and testing trial for exploration of the displaced object location. While $2 \mathrm{~N}$ mice spent more time exploring the displaced object than the nondisplaced one, Ts 2 mice did not show increased exploration time for the displaced object when compared with the nondisplaced object. However, the trisomic mice showed significantly higher exploration time for both nondisplaced and displaced objects than their disomic controls (Fig. 2B). This suggests that Ts2 mice may need more experience with the object before a clear relationship between object exploration and subsequent object preference emerges.

Similar results were obtained in the Y-maze test, which is another hippocampal-dependent spatial memory task. Ts2 mice 
showed decreased spontaneous alternation $(55.07 \pm 1.78)$ as compared with $2 \mathrm{~N}$ littermates (67.47 \pm 4.33; Fig. $2 C$ ), suggesting a compromised spatial working memory function. Ts2 mice were significantly more active when compared with their $2 \mathrm{~N}$ littermates, as determined by the total number of arm entries (Fig. 2D), suggesting hyperactivity. Similar to the nest-building behavior, we have not found a significant overall influence of sex on the behavior of mice in both the object-placement and the Y-maze tasks.

Reduced glutamate in the hippocampus of Ts 2 mice measured by ${ }^{1} \mathrm{H}$ MRS

The in vivo ${ }^{1} \mathrm{H}$ MR spectra were obtained by precise voxel of interest (VOI) placement in the hippocampus (Fig. 3A), using specific landmarks. The FASTMAP method achieved a full-width at halfmaximum (FWHM) shim of $<15 \mathrm{~Hz}$ for all animals used in this study. The ${ }^{1} \mathrm{H}$ MR spectra acquired were analyzed using LCModel and glutamate and GABA concentrations were quantified. Figure $3 B$ shows typical spectra from a $2 \mathrm{~N}$ mouse, with the major brain metabolites labeled. The glutamate-measured concentrations were quantified with Cramer Roa Lower Bound $(\mathrm{CRLB}) \leq 5 \%$ from the processed spectra. Glutamate concentration was found to be decreased in the hippocampal region of Ts2 mice as compared with $2 \mathrm{~N}$ mice (Fig. $3 C)$. Hippocampal GABA levels in Ts2 mice did not differ significantly from $2 \mathrm{~N}$ littermates.

\section{Reduced mRNA and protein levels of NMDA-R1 in the hippocampus of Ts2 mice}

Quantitative analysis showed that NMDA-R1 mRNA levels are downregulated in both CA1 and DG in Ts2 mice as compared with $2 \mathrm{~N}$ mice (Fig. $4 A$ ). We observed a trend toward downregulation $(p<0.07)$ in DLG4 mRNA expression in DG of Ts2 mice as compared with $2 \mathrm{~N}$ (data not shown) whereas there was no difference in mRNA expression levels of AMPA receptors GRIA1 and GRIA2 in CA1 and DG. A parallel significant downregulation of NMDA-R1 protein was found by Western blot analysis in hippocampal and hemibrain homogenates (Fig. 4B-D) in Ts 2 mice when compared with $2 \mathrm{~N}$ mice. No significant changes were found for other NMDA receptor subunits.

\section{Ts2 mouse model of DS exhibits aberrant hippocampal} glutamatergic transmission

Electrophysiological alterations

Paired-pulse analysis of perforant path-evoked responses recorded in the DG (Fig. 5A) was performed by calculating the average ratio of the slope of the second (test) evoked response to ${ }^{* * *} p<0.001$. at ${ }^{*} p<0.05$.
B

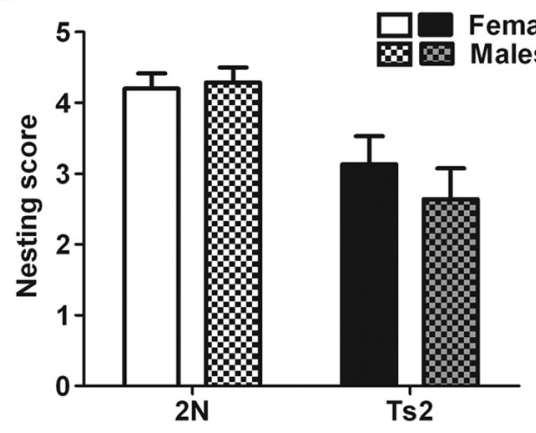

Figure 1. Deficits in nest construction behavior in the Ts 2 mouse model of DS. A, Nest construction by 8-month-old Ts 2 and $2 \mathrm{~N}$ mice. $2 \mathrm{~N}$ mice chewed the nestlets and organized them into well defined nests whereas Ts2 mice exhibited a significant deficit in nest building leaving the nestlets partially torn or as a poorly designed nest. $\boldsymbol{B}$, Males and females of both genotypes did not differ in nest-building behavior. All values are presented as mean \pm SD $(n=10-12)$. The differences from $2 \mathrm{~N}$ were significant at

A

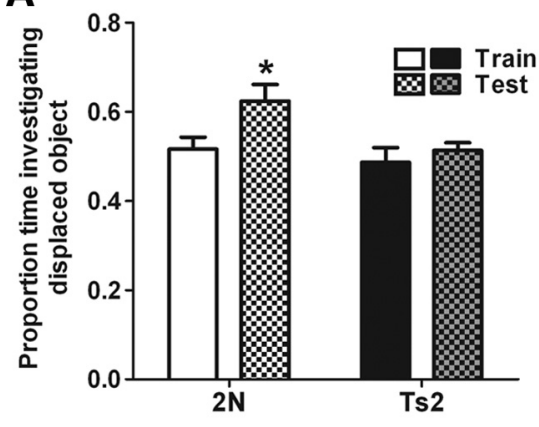

C

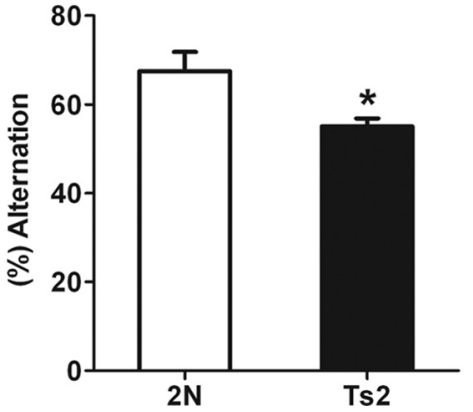

B

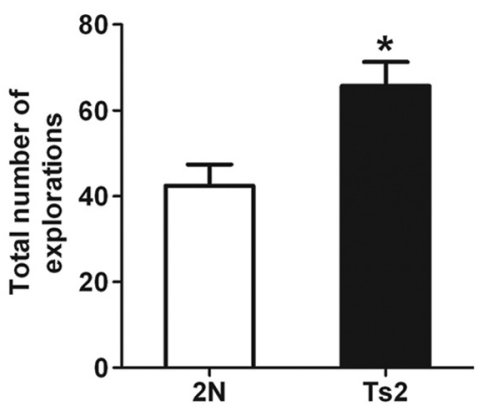

D

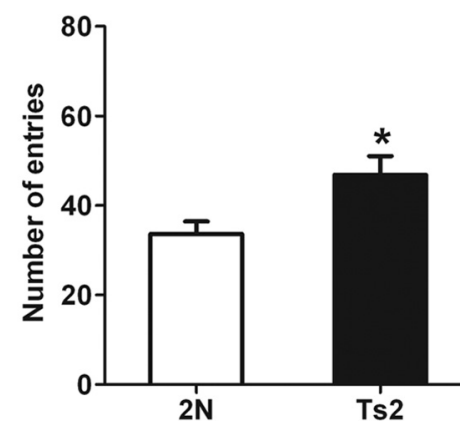

Figure 2. Ts2 mice showed a deficit in object recognition and spatial memory as measured by the object-placement and the Y-maze tasks. $\boldsymbol{A}$, The spatial memory task was well performed by $2 \mathrm{~N}$ mice, with a significant increase in sniff investigation of the moved object compared with the unmoved object. Ts 2 mice showed impaired spatial memory as compared with $2 \mathrm{~N}$ mice. $\boldsymbol{B}$, Ts2 mice showed an overall increased number of explorations for both objects as compared with $2 \mathrm{~N}$ mice. $\boldsymbol{C}$, Ts2 mice exhibited a significant deficit in spontaneous alternation behavior in the Y-maze task as compared with $2 \mathrm{~N}$ mice. D, Ts2 mice showed a significant increase in total number of arm entries in the $Y$-maze reflecting increased exploratory activities as compared with $2 \mathrm{~N}$ mice. All data are presented as mean \pm SEM $(n=10-12)$. The differences from $2 \mathrm{~N}$ were significant

the initial slope of the first (conditioning) evoked response. Pulses were given five times each at 20,50, 100, and 500 ms interstimulus intervals (ISI). $2 \mathrm{~N}$ mice showed significant paired-pulse facilitation at short ISIs. Ts2 mice exhibited less paired-pulse facilitation compared with $2 \mathrm{~N}$ at the 20,50 , and $100 \mathrm{~ms}$ pulse intervals and pairedpulse depression compared with $2 \mathrm{~N}$ at the $300 \mathrm{~ms}$ pulse interval (Fig. 5B,C). The impaired facilitation is consistent with a decrease in the storage pool of glutamate, leaving limited reserve for facilitated release on the test pulse (Zucker and Regehr, 2002), though enhanced feedback inhibition cannot be entirely ruled out based on these data. 
A

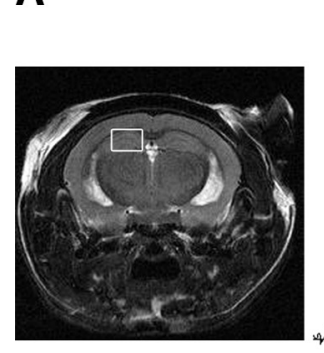

B

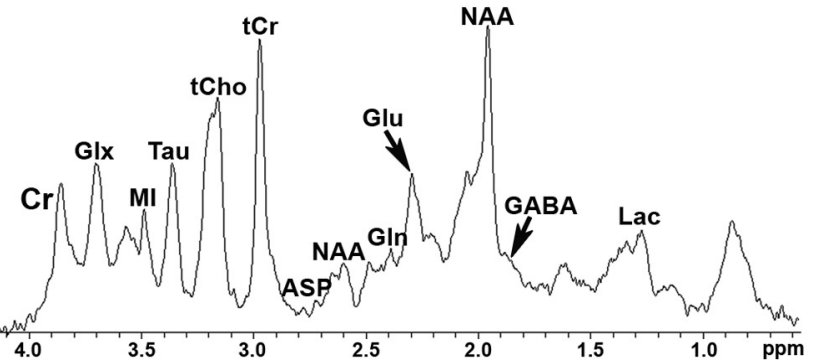

C

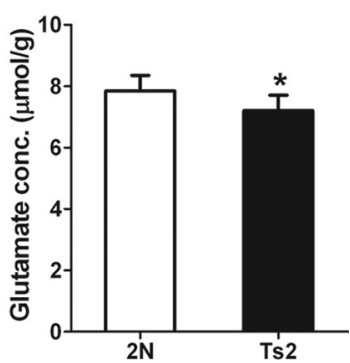

Figure 3. Decreased glutamate levels in hippocampal ${ }^{1} \mathrm{H}$ MRS metabolite measurements of Ts 2 mice as compared with disomic controls. $A$, The V0I size was $5 \mu \mathrm{l}\left(1 \times 2 \times 2.5 \mathrm{~mm}{ }^{3}\right)$ within the hippocampus. $\boldsymbol{B}$, Representative MR spectra from the hippocampus of a single $2 \mathrm{~N}$ mouse showing major labeled metabolites. $\boldsymbol{C}$, ${ }^{1} \mathrm{H}$ MRS glutamate concentration in Ts 2 versus $2 \mathrm{~N}$ mice in the hippocampus showed a significant difference in glutamate concentration. Cr, creatine; Lac, lactate; GABA, $\gamma$-aminobutyrate; NAA, N-acetyl aspartate; Glu, glutamate; Gln, glutamine; ASP, aspartate; $\mathrm{tCr}$, total creatine; tCho, total choline; tau, taurine; $\mathrm{Ml}$, myo-inositol; Glx, glutamate + glutamine. All data are presented as mean \pm SEM $(n=7)$. The differences from $2 \mathrm{~N}$ were significant at ${ }^{*} p<0.05$.

A

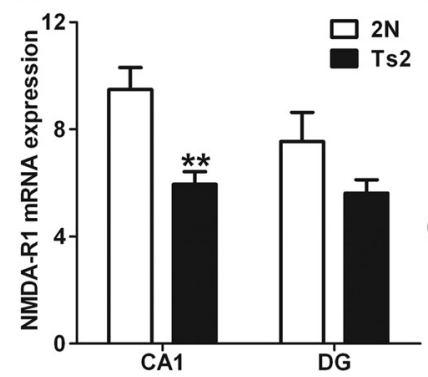

B

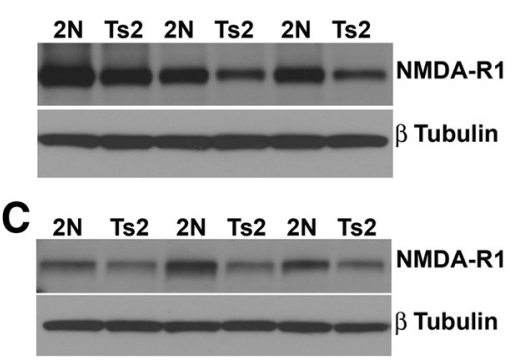

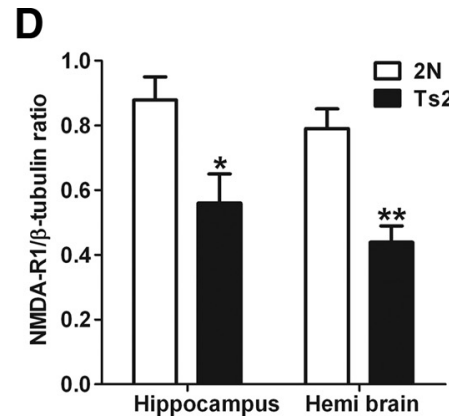

Figure 4. Reduced NMDA-R1 mRNA and protein expression levels in Ts2 mice. $A$, NMDA-R1 mRNA expression levels as shown by qPCR analysis of GRIN1 are represented as ddCT values in the CA1 and DG regions comparing Ts2 and 2N mice. Measurements are presented as mean $\pm S D(n=7)$. Significance set at ${ }^{* *} p<0.01$. Western blot analyses of hippocampal (B) and hemibrain $(\boldsymbol{C})$ homogenates, with anti- NMDA-R1 antibody confirmed a decrease in NMDA receptor expression levels in Ts2 mice compared with 2N mice. Quantification of the ratio of NMDA-R1 to $\beta$-tubulin bands, presented as the mean \pm SD $(n=6 ; \boldsymbol{D})$. The differences from WT were significant at ${ }^{*} p<0.05,{ }^{* *} p<0.01$.
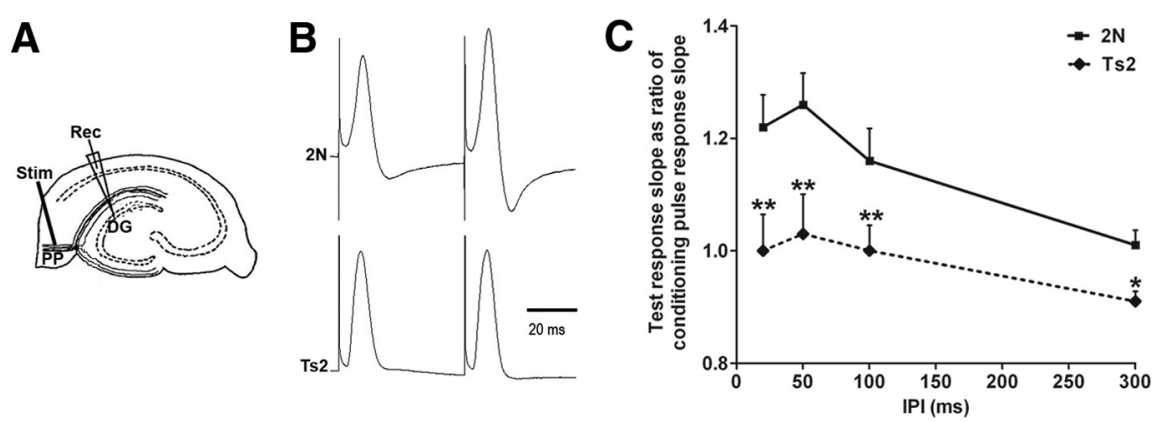

Figure 5. Paired-pulse analysis of local synaptic function in the hippocampus. A, A schematic diagram showing the positions of the stimulating (Stim) and recording (Rec) electrodes in the perforant path (PP) and the dentate gyrus (DG) region of the hippocampus, respectively. $\boldsymbol{B}$, Representative paired-pulse responses of $2 \mathrm{~N}$ and Ts 2 mice at the $50 \mathrm{~ms}$ ISI. Scale bar, $20 \mathrm{~ms}$. C, Chart showing paired-pulse responses of $2 \mathrm{~N}$ (solid) versus Ts2 (dotted) mice at 20,50, 100, and $300 \mathrm{~ms} \mathrm{ISI}$. Time interval is plotted on the $x$-axis with the ratio of the test response to the conditioning response on the $y$-axis. Ts2 mice demonstrated significantly lower paired-pulse facilitation compared with $2 \mathrm{~N}$ at the first three $\mathrm{ISIs}(20,50$, and $100 \mathrm{~ms}$; repeated-measures ANOVA, genotype $\times|S|$, $F_{(1,36)}=9.97, p<0.01$ ). Ts2 mice showed paired-pulse depression compared with $2 \mathrm{~N}$ at the $300 \mathrm{ISI}$ (post hoc Fisher tests, $p<$ $0.05)$. All data are presented as mean $\pm \operatorname{SEM}(n=7)$. The differences from $2 \mathrm{~N}$ were significant at ${ }^{*} p<0.05$, ${ }^{* *} p<0.01$.

Normal basal synaptic transmission but impaired LTP in the Schaffer collateral pathway of the hippocampus in Ts2 mice We first determined the input/output responses in the Schaffer collateral pathway of hippocampal slices (Fig. 6A) prepared from $2 \mathrm{~N}$ and $\mathrm{Ts} 2$ mice. The robust input/output responses were evoked by increasing stimulus intensity in both genotypes. The input/ output curve was not different in Ts2 mice compared with $2 \mathrm{~N}$ littermates (Fig. 6B). Before tetanic stimulations, baseline fEPSP was recorded in $60 \mathrm{~s}$ intervals with stimulation at an intensity equivalent to $\sim 35 \%$ of the maximum evoked response. Tetanic stimulation evoked typical LTP (Fig. 6C) in slices from $2 \mathrm{~N}$ mice. These responses were stable over $120 \mathrm{~min}$. However, tetanic stimulation evoked a significantly reduced LTP magnitude in slices prepared from Ts2 compared with $2 \mathrm{~N}$ mice. Results suggest that LTP was significantly impaired in Ts2 mice compared with $2 \mathrm{~N}$ littermates (Fig. $6 D)$. These results collectively suggest that Ts2 mice have normal basal neurotransmission but impaired CA1 hippocampal synaptic plasticity.

\section{Discussion}

DS patients have intellectual disabilities with individual variability in the severity of both physiological and behavioral phenotypes. At the core of the intellectual disabilities is the phenomenon of synaptic plasticity, a functional change in the strength at the points of communication between neurons (Cramer and Galdzicki, 2012). Our study focused on the hippocampal glutamatergic aberrations, NMDA receptor dysregulation, and resulting behavioral anomalies in the trisomic mouse model, Ts2. We used in vivo MRS for detecting glutamate concentrations in the hippocampus, which is a noninvasive method to retrieve neurotransmitter concentration in live animals. We found a significant reduction in glutamate concentration in the hippocampus in Ts 2 mice as compared with $2 \mathrm{~N}$ mice. Improvement for GABA detection could be made using a 
spectral editing approach, nonetheless the direct excitation method used did not detect a statistically significant decrease in GABA concentration.

Glutamate diminution and vulnerability of glutamatergic synapses have been reported in patients with DS and AD (Reynolds and Warner, 1988; Risser et al., 1997; Hynd et al., 2004; Proctor et al., 2010; Rueda et al., 2012; Canas et al., 2014) but a direct involvement of glutamate in cognitive decline have not been demonstrated in patients. Previous reports suggested that a deficit in hippocampal glutamate levels occurs in adult DS (Reynolds and Warner, 1988; Risser et al., 1997), correlating with the extent of cognitive disabilities of these patients (Risser et al., 1997). While hippocampal glutamate loss appears to be a distinctive pathological feature in DS (Reynolds and Warner, 1988; Risser et al., 1997), in AD the loss is greater in the frontal and temporal cortices (Sasaki et al., 1986). In the context of overall cognitive disabilities, hippocampal dysfunction was found in school-aged DS individuals (Pennington et al., 2003; Boada et al., 2012), long before the development of overt neuropathological hallmarks of AD. Ts2 mice do not develop extracellular amyloid- $\beta$ pathology, and therefore, the glutamate decrease observed in 8-month-old Ts2 mice simulates early changes in the brain of DS patients, before the development of AD-like pathology.

Decreased mRNA expression levels of NMDA-R1 in the CA1 and DG of the hippocampus of Ts2 mice correlates with downregulated protein expression levels. These findings are consistent with decreased glutamate transporter expression level and uptake of glutamate that were previously found in $\mathrm{AD}$ (Scott et al., 2011; Scimemi et al., 2013). The lower levels of vesicular glutamate and excitatory amino acid transporters observed in prefrontal and parietal cortices of AD brains (Kirvell et al., 2006; Parsons et al., 2007; Kashani et al., 2008) may indicate reduced glutamate metabolism or altered turnover (Esposito et al., 2013).

Decrease in hippocampal glutamate concentration and NMDA receptors could explain the aberrant paired-pulse facilitation and further synaptic dysfunctions recorded in the Ts2 mouse model of DS. We suggest that decreased paired-pulse facilitation in the hippocampus in Ts2 mice is an outcome of excitation/inhibition imbalance in hippocampal networks, probably initiated by an impaired glutamatergic system, with a decrease in the amount of presynaptic glutamate available for release the most likely candidate mechanism (Zucker and Regehr, 2002; Cramer and Galdzicki, 2012).

Reduced activation of NMDA receptors had been reported in the Ts65Dn mouse model and was thought to hinder LTP induction in these mice (Kleschevnikov et al., 2004; Rueda et al., 2012). Enhanced hippocampal LTD had also been reported in the Ts65Dn mouse (Siarey et al., 1999). Furthermore, it was demonstrated that selective GABA and NMDA receptor antagonists can reverse functional and neuromorphological deficits of Ts65Dn mice by facilitating brain plasticity, supporting the potential therapeutic use of these selective antagonists to treat cognitive dys-
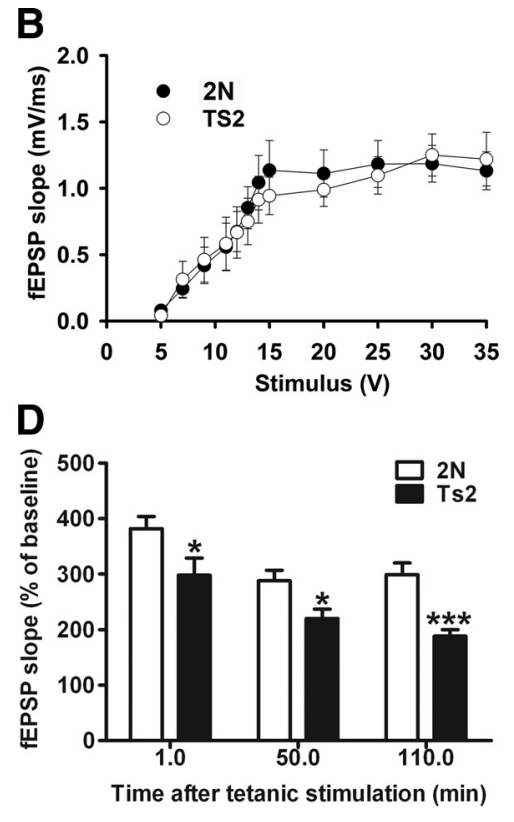

Figure 6. LTP is impaired in Ts2 mice. $\boldsymbol{A}$, A schematic diagram of the stimulating (Stim) and recording (Rec) electrode positions in the CA1 region of the hippocampus. $B, A$ summary graph showing the field input/output relationships for $2 \mathrm{~N}$ and Ts2 mice. A Co fePSP slopes from the slices obtained from $2 \mathrm{~N}$ and Ts2 mice did not show significant difference. of tetanic stimulation (4 pulses at $100 \mathrm{~Hz}$, with bursts repeated at $5 \mathrm{~Hz}$, and each tetanus including three 10 burst trains separated s). Tetanic stimulation evoked a reduced LTP magnitude in slices prepared from Ts 2 compared with $2 \mathrm{~N}$ mice. D, A combined plot of the averages of fEPSP slopes at several time points showed a significant decrease in Ts 2 as compared with $2 \mathrm{~N}$ mice. Each point is the mean \pm SEM ( $n=5$ mice/group; 10 slices/group). The differences from $2 \mathrm{~N}$ were significant at ${ }^{*} p<0.05,{ }^{* * *} p<0.001$.

function in DS (Boada et al., 2012; Danysz and Parsons, 2012; Kleschevnikov et al., 2012; Colas et al., 2013; Hanson et al., 2013; Martínez-Cué et al., 2013). Memantine, an uncompetitive NMDA receptor antagonist, has been shown in clinical trials to be beneficial in patients with moderate to severe $\mathrm{AD}$ (Reisberg et al., 2003, 2006; Porsteinsson et al., 2008; Wang et al., 2013). Memantine has also been found to rescue abnormal synaptic plasticity in Ts65Dn mice (Lockrow et al., 2011; Scott-McKean and Costa, 2011). However, the ameliorative effects of memantine have yet to be demonstrated in adult DS patients (Boada et al., 2012; Hanney et al., 2012).

Ts2 mice display a deficit in nest-building behavior, which is a measure of hippocampus-dependent nonlearned innate behavior (Deacon et al., 2002; Duszczyk et al., 2006). Overexpression of mutant APP (independent of amyloid- $\beta$ ) may initiate the cascade toward deficient nesting behaviors in APP transgenic mice (Filali and Lalonde, 2009; Wesson and Wilson, 2011; Cramer et al., 2012). Similarly, APP triplication in Ts 2 mice may drive the nesting dysfunction observed in these mice. However, memantine administration in APP/PS1 mutant mice could recover the nesting dysfunction but did not quite reach significance (Filali et al., 2011). Moreover, testing in the object-placement task and the Y-maze spontaneous alternations task, which are hippocampusdependent spatial memory tests, showed that Ts2 mice exhibit cognitive deficits as compared with $2 \mathrm{~N}$ littermates. Our data suggest that impaired NMDA-R1 function may lead to functional disconnection within the hippocampal circuit that might cause LTP impairments in Ts2 mice. The behavioral and physiological characterizations of glutamatergic deficits in Ts2 mice presented here support a therapeutic approach using modulators of glutamatergic neurotransmission in DS patients. 
In conclusion, our results indicate that hippocampal glutamate downregulation, NMDA-R1 receptor dysregulation, and both presynaptic and postsynaptic dysfunction at glutamatergic synapses may contribute to behavioral impairments in the Ts2 mouse model of DS. Significant glutamatergic deficits observed in DS subjects and experimental models indicate that these alterations may cause intellectual disabilities. This study defines glutamatergic aberrations as a distinctive early pathology and suggests that GABA-mediated synaptic inhibition as seen in other DS studies may associate with glutamatergic alterations to bring upon synaptic changes and cognitive deficits in DS models. Thus, glutamatergic dysfunction may play a key role in the hippocampal pathogenesis of $\mathrm{AD}$ and $\mathrm{DS}$.

\section{References}

Alldred MJ, Che S, Ginsberg SD (2008) Terminal Continuation (TC) RNA amplification enables expression profiling using minute RNA input obtained from mouse brain. Int J Mol Sci 9:2091-2104. CrossRef Medline

Alldred MJ, Duff KE, Ginsberg SD (2012) Microarray analysis of CA1 pyramidal neurons in a mouse model of tauopathy reveals progressive synaptic dysfunction. Neurobiol Dis 45:751-762. CrossRef Medline

Bar-Peled O, Gross-Isseroff R, Ben-Hur H, Hoskins I, Groner Y, Biegon A (1991) Fetal human brain exhibits a prenatal peak in the density of serotonin 5-HT1A receptors. Neurosci Lett 127:173-176. CrossRef Medline

Basavarajappa BS, Subbanna S (2014) CB1 receptor-mediated signaling underlies the hippocampal synaptic, learning and memory deficits following treatment with JWH-081, a new component of spice/K2 preparations. Hippocampus 24:178-188. CrossRef Medline.

Best TK, Cramer NP, Chakrabarti L, Haydar TF, Galdzicki Z (2012) Dysfunctional hippocampal inhibition in the Ts65Dn mouse model of Down syndrome. Exp Neurol 233:749-757. CrossRef Medline

Bhattacharyya A, McMillan E, Chen SI, Wallace K, Svendsen CN (2009) A critical period in cortical interneuron neurogenesis in Down syndrome revealed by human neural progenitor cells. Dev Neurosci 31:497-510. CrossRef Medline

Boada R, Hutaff-Lee C, Schrader A, Weitzenkamp D, Benke TA, Goldson EJ, Costa AC (2012) Antagonism of NMDA receptors as a potential treatment for Down syndrome: a pilot randomized controlled trial. Transl Psychiatry 2:e141. CrossRef Medline

Bottomley PA (1987) Spatial localization in NMR spectroscopy in vivo. Ann N Y Acad Sci 508:333-348. CrossRef Medline

Canas PM, Simões AP, Rodrigues RJ, Cunha RA (2014) Predominant loss of glutamatergic terminal markers in a $\beta$-amyloid peptide model of Alzheimer's disease. Neuropharmacology 76:51-56. CrossRef Medline

Cataldo AM, Peterhoff CM, Troncoso JC, Gomez-Isla T, Hyman BT, Nixon RA (2000) Endocytic pathway abnormalities precede amyloid $\beta$ deposition in sporadic Alzheimer's disease and Down syndrome: differential effects of APOE genotype and presenilin mutations. Am J Pathol 157:277286. CrossRef Medline

Colas D, Chuluun B, Warrier D, Blank M, Wetmore DZ, Buckmaster P, Garner CC, Heller HC (2013) Short-term treatment with the GABAA receptor antagonist pentylenetetrazole produces a sustained procognitive benefit in a mouse model of Down's syndrome. Br J Pharmacol 169:963-973. CrossRef Medline

Costa AC, Scott-McKean JJ, Stasko MR (2008) Acute injections of the NMDA receptor antagonist memantine rescue performance deficits of the Ts65Dn mouse model of Down syndrome on a fear conditioning test. Neuropsychopharmacology 33:1624-1632. CrossRef Medline

Cramer N, Galdzicki Z (2012) From abnormal hippocampal synaptic plasticity in Down syndrome mouse models to cognitive disability in Down syndrome. Neural Plast 2012:101542. CrossRef Medline

Cramer PE, Cirrito JR, Wesson DW, Lee CY, Karlo JC, Zinn AE, Casali BT, Restivo JL, Goebel WD, James MJ, Brunden KR, Wilson DA, Landreth GE (2012) ApoE-directed therapeutics rapidly clear $\beta$-amyloid and reverse deficits in AD mouse models. Science 335:1503-1506. CrossRef Medline

Danysz W, Parsons CG (2012) Alzheimer's disease, $\beta$-amyloid, glutamate, NMDA receptors and memantine-searching for the connections. $\mathrm{Br} \mathrm{J}$ Pharmacol 167:324-352. CrossRef Medline

Das I, Reeves RH (2011) The use of mouse models to understand and improve cognitive deficits in Down syndrome. Dis Model Mech 4:596-606. CrossRef Medline
Davisson MT, Schmidt C, Akeson EC (1990) Segmental trisomy of murine chromosome 16: a new model system for studying Down syndrome. Prog Clin Biol Res 360:263-280. Medline

Deacon RM (2006) Assessing nest building in mice. Nat Protoc 1:11171119. CrossRef Medline

Deacon RM, Croucher A, Rawlins JN (2002) Hippocampal cytotoxic lesion effects on species-typical behaviours in mice. Behav Brain Res 132:203213. CrossRef Medline

Devi L, Alldred MJ, Ginsberg SD, Ohno M (2010) Sex- and brain regionspecific acceleration of $\beta$-amyloidogenesis following behavioral stress in a mouse model of Alzheimer's disease. Mol Brain 3:34. CrossRef Medline

Duszczyk M, Ziembowicz A, Gadamski R, Lazarewicz JW (2006) Behavioral evaluation of ischemic damage to CA1 hippocampal neurons: effects of preconditioning. Acta Neurobiol Exp 66:311-319. Medline

Esposito Z, Belli L, Toniolo S, Sancesario G, Bianconi C, Martorana A (2013) Amyloid $\beta$, glutamate, excitotoxicity in Alzheimer's disease: are we on the right track? CNS Neurosci Ther 19:549-555. CrossRef Medline

Filali M, Lalonde R (2009) Age-related cognitive decline and nesting behavior in an APPswe/PS1 bigenic model of Alzheimer's disease. Brain Res 1292:93-99. CrossRef Medline

Filali M, Lalonde R, Rivest S (2011) Subchronic memantine administration on spatial learning, exploratory activity, and nest-building in an APP/PS1 mouse model of Alzheimer's disease. Neuropharmacology 60:930-936. CrossRef Medline

Ginsberg SD (2008) Transcriptional profiling of small samples in the central nervous system. Methods Mol Biol 439:147-158. CrossRef Medline

Godridge H, Reynolds GP, Czudek C, Calcutt NA, Benton M (1987) Alzheimer-like neurotransmitter deficits in adult Down's syndrome brain tissue. J Neurol Neurosurg Psychiatry 50:775-778. CrossRef Medline

Granholm AC, Sanders LA, Crnic LS (2000) Loss of cholinergic phenotype in basal forebrain coincides with cognitive decline in a mouse model of Down's syndrome. Exp Neurol 161:647-663. CrossRef Medline

Gruetter R (1993) Automatic, localized in vivo adjustment of all first- and second-order shim coils. Magn Reson Med 29:804-811. CrossRef Medline

Hanney M, Prasher V, Williams N, Jones EL, Aarsland D, Corbett A, Lawrence D, Yu LM, Tyrer S, Francis PT, Johnson T, Bullock R, Ballard C (2012) Memantine for dementia in adults older than 40 years with Down's syndrome (MEADOWS): a randomised, double-blind, placebocontrolled trial. Lancet 379:528-536. CrossRef Medline

Hanson JE, Weber M, Meilandt WJ, Wu T, Luu T, Deng L, Shamloo M, Sheng M, Scearce-Levie K, Zhou Q (2013) GluN2B antagonism affects interneurons and leads to immediate and persistent changes in synaptic plasticity, oscillations, and behavior. Neuropsychopharmacology 38: 1221-1233. CrossRef Medline

Holtzman DM, Santucci D, Kilbridge J, Chua-Couzens J, Fontana DJ, Daniels SE, Johnson RM, Chen K, Sun Y, Carlson E, Alleva E, Epstein CJ, Mobley WC (1996) Developmental abnormalities and age-related neurodegeneration in a mouse model of Down syndrome. Proc Natl Acad Sci U S A 93:13333-13338. CrossRef Medline

Hughes RN (2004) Responsiveness to brightness change in male and female rats following treatment with the partial agonist of the N-methyl-D-aspartate receptor, D-cycloserine. Behav Brain Res 152:199-207. CrossRef Medline

Hynd MR, Scott HL, Dodd PR (2004) Selective loss of NMDA receptor NR1 subunit isoforms in Alzheimer's disease. J Neurochem 89:240-247. CrossRef Medline

Kang J, Lemaire HG, Unterbeck A, Salbaum JM, Masters CL, Grzeschik KH, Multhaup G, Beyreuther K, Müller-Hill B (1987) The precursor of Alzheimer's disease amyloid A4 protein resembles a cell-surface receptor. Nature 325:733-736. CrossRef Medline

Kashani A, Lepicard E, Poirel O, Videau C, David JP, Fallet-Bianco C, Simon A, Delacourte A, Giros B, Epelbaum J, Betancur C, El Mestikawy S (2008) Loss of VGLUT1 and VGLUT2 in the prefrontal cortex is correlated with cognitive decline in Alzheimer disease. Neurobiol Aging 29:1619-1630. CrossRef Medline

Kirvell SL, Esiri M, Francis PT (2006) Down-regulation of vesicular glutamate transporters precedes cell loss and pathology in Alzheimer's disease. J Neurochem 98:939-950. CrossRef Medline

Kleschevnikov AM, Belichenko PV, Villar AJ, Epstein CJ, Malenka RC, Mobley WC (2004) Hippocampal long-term potentiation suppressed by increased inhibition in the Ts65Dn mouse, a genetic model of Down syndrome. J Neurosci 24:8153-8160. CrossRef Medline 
Kleschevnikov AM, Belichenko PV, Faizi M, Jacobs LF, Htun K, Shamloo M, Mobley WC (2012) Deficits in cognition and synaptic plasticity in a mouse model of Down syndrome ameliorated by GABAB receptor antagonists. J Neurosci 32:9217-9227. CrossRef Medline

Leverenz JB, Raskind MA (1998) Early amyloid deposition in the medial temporal lobe of young Down syndrome patients: a regional quantitative analysis. Exp Neurol 150:296-304. CrossRef Medline

Levine S, Saltzman A, Levy E, Ginsberg SD (2009) Systemic pathology in aged mouse models of Down's syndrome and Alzheimer's disease. Exp Mol Pathol 86:18-22. CrossRef Medline

Lockrow J, Boger H, Bimonte-Nelson H, Granholm AC (2011) Effects of long-term memantine on memory and neuropathology in Ts65Dn mice, a model for Down syndrome. Behav Brain Res 221:610-622. CrossRef Medline

Lott IT (2012) Neurological phenotypes for Down syndrome across the life span. Prog Brain Res 197:101-121. CrossRef Medline

Lott IT, Dierssen M (2010) Cognitive deficits and associated neurological complications in individuals with Down's syndrome. Lancet Neurol 9:623-633. CrossRef Medline

Luine VN, Jacome LF, Maclusky NJ (2003) Rapid enhancement of visual and place memory by estrogens in rats. Endocrinology 144:2836-2844. CrossRef Medline

Macbeth AH, Gautreaux C, Luine VN (2008) Pregnant rats show enhanced spatial memory, decreased anxiety, and altered levels of monoaminergic neurotransmitters. Brain Res 1241:136-147. CrossRef Medline

Martínez-Cué C, Martínez P, Rueda N, Vidal R, García S, Vidal V, Corrales A, Montero JA, Pazos Á, Flórez J, Gasser R, Thomas AW, Honer M, Knoflach F, Trejo JL, Wettstein JG, Hernández MC (2013) Reducing GABAA $\alpha 5$ receptor-mediated inhibition rescues functional and neuromorphological deficits in a mouse model of Down syndrome. J Neurosci 33:39533966. CrossRef Medline

Oka A, Takashima S (1999) The up-regulation of metabotropic glutamate receptor 5 (mGluR5) in Down's syndrome brains. Acta Neuropathol 97: 275-278. CrossRef Medline

Parsons CG, Stöffler A, Danysz W (2007) Memantine: a NMDA receptor antagonist that improves memory by restoration of homeostasis in the glutamatergic system-too little activation is bad, too much is even worse. Neuropharmacology 53:699-723. CrossRef Medline

Paxinos G, Franklin KBJ (2000) The mouse brain in stereotaxic coordinates. Ed 3. San Diego: Academic.

Pennington BF, Moon J, Edgin J, Stedron J, Nadel L (2003) The neuropsychology of Down syndrome: evidence for hippocampal dysfunction. Child Dev 74:75-93. CrossRef Medline

Porsteinsson AP, Grossberg GT, Mintzer J, Olin JT (2008) Memantine treatment in patients with mild to moderate Alzheimer's disease already receiving a cholinesterase inhibitor: a randomized, double-blind, placebo-controlled trial. Curr Alzheimer Res 5:83-89. CrossRef Medline

Proctor DT, Coulson EJ, Dodd PR (2010) Reduction in post-synaptic scaffolding PSD-95 and SAP-102 protein levels in the Alzheimer inferior temporal cortex is correlated with disease pathology. J Alzheimers Dis 21:795-811. CrossRef Medline

Provencher SW (1993) Estimation of metabolite concentrations from localized in vivo proton NMR spectra. Magn Reson Med 30:672-679. CrossRef Medline

Reisberg B, Doody R, Stöffler A, Schmitt F, Ferris S, Möbius HJ (2003) Memantine in moderate-to-severe Alzheimer's disease. N Engl J Med 348: 1333-1341. CrossRef Medline

Reisberg B, Doody R, Stöffler A, Schmitt F, Ferris S, Möbius HJ (2006) A 24-week open-label extension study of memantine in moderate to severe Alzheimer disease. Arch Neurol 63:49-54. CrossRef Medline

Reynolds GP, Warner CE (1988) Amino acid neurotransmitter deficits in adult Down's syndrome brain tissue. Neurosci Lett 94:224-227. CrossRef Medline
Risser D, Lubec G, Cairns N, Herrera-Marschitz M （1997） Excitatory amino acids and monoamines in parahippocampal gyrus and frontal cortical pole of adults with Down syndrome. Life Sci 60:1231-1237. CrossRef Medline

Rueda N, Flórez J, Martínez-Cué C (2012) Mouse models of Down syndrome as a tool to unravel the causes of mental disabilities. Neural Plast 2012:584071. CrossRef Medline

Sasaki H, Muramoto O, Kanazawa I, Arai H, Kosaka K, Iizuka R (1986) Regional distribution of amino acid transmitters in postmortem brains of presenile and senile dementia of Alzheimer type. Ann Neurol 19:263-269. CrossRef Medline

Scimemi A, Meabon JS, Woltjer RL, Sullivan JM, Diamond JS, Cook DG (2013) Amyloid- $\beta 1-42$ slows clearance of synaptically released glutamate by mislocalizing astrocytic GLT-1. J Neurosci 33:5312-5318. CrossRef Medline

Scott HA, Gebhardt FM, Mitrovic AD, Vandenberg RJ, Dodd PR (2011) Glutamate transporter variants reduce glutamate uptake in Alzheimer's disease. Neurobiol Aging 32:553.e1-511. CrossRef Medline

Scott-McKean JJ, Costa AC (2011) Exaggerated NMDA mediated LTD in a mouse model of Down syndrome and pharmacological rescuing by memantine. Learn Mem 18:774-778. CrossRef Medline

Sheehan R, Ali A, Hassiotis A (2014) Dementia in intellectual disability. Curr Opin Psychiatry 27:143-148. CrossRef Medline

Siarey RJ, Carlson EJ, Epstein CJ, Balbo A, Rapoport SI, Galdzicki Z (1999) Increased synaptic depression in the Ts65Dn mouse, a model for mental retardation in Down syndrome. Neuropharmacology 38:1917-1920. CrossRef Medline

Siarey RJ, Kline-Burgess A, Cho M, Balbo A, Best TK, Harashima C, Klann E, Galdzicki Z (2006) Altered signaling pathways underlying abnormal hippocampal synaptic plasticity in the Ts65Dn mouse model of Down syndrome. J Neurochem 98:1266-1277. CrossRef Medline

Tkác I, Starcuk Z, Choi IY, Gruetter R (1999) In vivo 1H NMR spectroscopy of rat brain at $1 \mathrm{~ms}$ echo time. Magn Reson Med 41:649-656. CrossRef Medline

Villar AJ, Belichenko PV, Gillespie AM, Kozy HM, Mobley WC, Epstein CJ (2005) Identification and characterization of a new Down syndrome model, $\mathrm{Ts}[\mathrm{Rb}(12.1716)] 2 \mathrm{Cje}$, resulting from a spontaneous Robertsonian fusion between $\mathrm{T}(171) 65 \mathrm{Dn}$ and mouse chromosome 12. Mamm Genome 16:79-90. Medline

Wang T, Huang Q, Reiman EM, Chen K, Li X, Li G, Lin Z, Li C, Xiao S (2013) Effects of memantine on clinical ratings, fluorodeoxyglucose positron emission tomography measurements, and cerebrospinal fluid assays in patients with moderate to severe Alzheimer dementia: a 24-week, randomized, clinical trial. J Clin Psychopharmacol 33:636-642. CrossRef Medline

Wesson DW, Wilson DA (2011) Age and gene overexpression interact to abolish nesting behavior in Tg2576 amyloid precursor protein (APP) mice. Behav Brain Res 216:408-413. CrossRef Medline

Whittle N, Sartori SB, Dierssen M, Lubec G, Singewald N (2007) Fetal Down syndrome brains exhibit aberrant levels of neurotransmitters critical for normal brain development. Pediatrics 120:e1465-1471. CrossRef Medline

Wisniewski KE, Laure-Kamionowska M, Wisniewski HM (1984) Evidence of arrest of neurogenesis and synaptogenesis in brains of patients with Down's syndrome. N Engl J Med 311:1187-1188. CrossRef Medline

Wisniewski KE, Wisniewski HM, Wen GY (1985) Occurrence of neuropathological changes and dementia of Alzheimer's disease in Down's syndrome. Ann Neurol 17:278-282. CrossRef Medline

Yates CM, Simpson J, Gordon A (1986) Regional brain 5-hydroxytryptamine levels are reduced in senile Down's syndrome as in Alzheimer's disease. Neurosci Lett 65:189-192. CrossRef Medline

Zucker RS, Regehr WG (2002) Short-term synaptic plasticity. Annu Rev Physiol 64:355-405. CrossRef Medline 